Journal of Contextual Economics 139 (2019), 213-224

Duncker \& Humblot, Berlin

\title{
Is There an Agenda of Neoliberal Emancipation?
}

\author{
By Erwin Dekker*
}

\begin{abstract}
This paper argues that one of the weaknesses of the neoliberals of the 1940s was their failure to develop a positive program of individual emancipation. It is demonstrated that in conversation with the critics of neoliberalism (Foucault, Cooper, and others) such an agenda can be developed. To do so we should disentangle the neoliberal agenda from the conservative social agenda with which it has long been associated. It is argued that in particular the Chicago School approach to the individual and social conditions such as the modern workplace, online communities and city life provides inspiration for an agenda of neoliberal emancipation.
\end{abstract}

JEL Codes: A13, B20, B53, P16, Z13

\section{Reclaiming the Future}

A number of classic neoliberal books diagnose their contemporaries as suffering from a deep fatalism. It is the leading problem in the ordoliberal manifesto of 1936 (Böhm, Eucken, and Großmann-Doerth 1989), it is the central problem of the introduction to Karl Popper's Open Society and its Enemies (1945b), and a dominant motif in the introduction of Friedrich Hayek's Road to Serfdom (1944). In the reminiscences of Ludwig von Mises written in 1940, it is even presented as a sad realization: "I set out to be a reformer, but became the historian of decline" (Mises 1978, 115).

What is curious in these books is that fatalism is identified both with a historicist position (there are laws of history which cannot be escaped) and with positivism (we can only explain the world, not alter it). In my book The Viennese Students of Civilization (Dekker 2016) I have suggested that the analysis should also be read as a critique of the liberal tradition itself. The liberal emphasis on a natural order and harmony wrongly suggested that liberalism was the logical outcome of history

* Erasmus School of History, Culture and Communication, Erasmus University Rotterdam, Burgemeester Oudlaan 50, 3062 PA Rotterdam, Netherlands. The author can be reached at e.dekker@eshcc.eur.nl. 
(Rüstow 1945). And the dominance of liberalism in intellectual circles during the $19^{\text {th }}$ century wrongly suggested that its superiority was demonstrated by science.

In other words, leading up to about 1914 liberalism had become complacent (Wieser 1910). The interwar period did much to shake up this complacency. Socialism became a real possibility, fascism changed the way politics was done, and the Great Depression suggested that the liberal order had no answers to modern economic challenges. One might argue that a similar complacency had been reached during the 1990s. Francis Fukuyama famously proclaimed the end of history, and the fall of the communism seemed to suggest that liberalism was the end-point of history after all. The idea that liberalism was not primarily an ideology, but rather a set of procedures or the outcome of rational deliberation from a position of neutrality was perhaps nowhere clearer than in the work of John Rawls, whose work was the cornerstone of modern political thought. His original position was an attempt to show that all reasonable people should be attracted to liberalism, the work even had some appeal to James Buchanan, certainly no complacent liberal.

One might therefore say that a reconsideration of these two critiques, historical necessity and the supposed neutrality of liberalism, are in order. The attitude, at least among Viennese liberals, had been that of students who had studied a kind of benevolent social order and the emergence of institutions that facilitated peaceful living together. They now had to act as custodians, or shepherds, of those very institutions. But this in turn posed a greater problem, for how could they prevent being merely looked at as conservatives? If after all they merely defended the existing and in fact decaying order, they could perhaps postpone the future a little, but not avoid its coming.

What was needed was something more significant; it was reclaiming the future. And so they argued, Popper most famously, that the future was open. This was a dangerous position, after all much of their previous work had cautioned against revolutionary change and argued that one could not shape the future at will (often in the form: socialism is not possible). Now they instead had to propose a vision for the future that was possible, feasible, realistic, but also hopeful. That, I believe, is why Hayek argued 'for the courage' for utopias. It was not a gratuitous remark, but a sign of a fundamental shift in attitude.

I think in my book I did not do that shift enough justice, and emphasized too much the custodian aspect, the way in which the Viennese liberals sought to protect certain social institutions and arrangements, and too little how they sought to be utopian again. In this the neoliberals sought to avoid the position of the social engineer - it was their arch-nemesis, an even bigger danger than fatalism. In a recent article I have attempted to correct this, and have explored what a more emancipatory (neo-)liberal position entails (Dekker 2019). By choosing the notion of emancipation, I also hope to stress that this historically has been one of the strengths of liberalism. It was a program of emancipation of disenfranchised individuals and groups in society, and it has lost 
much of that appeal. I do not think that the neoliberals of the 1940s managed to fully rekindle this spirit, but I believe that is the way forward this time.

In this essay I wish to explore what such a shift toward an emancipatory and forward-looking perspective might entail in our own age.

\section{Emancipation Among the Neoliberals of the 1940s}

There were, according to the early neoliberals, two main problems during the interwar period, which hampered the emancipation of the individual. On the one hand there was mass unemployment, which had robbed individuals of the possibility to take care of themselves. On the other hand full-suffrage democracy had given way to mass politics which, contrary to expectations, did not empower individuals but instead oppressed them.

The problem of unemployment was to be solved by a more active employment policy, although neoliberals could not quite agree what these policies should be (Grudev 2018). Some of the German neo-liberals favored countercyclical policies to avoid the worst effects of the business cycle - if that was what it took. Others believed that by making markets more competitive, including the labor market, the mass unemployment of the 1930s could be prevented. It was recognized among at least a part of the early neoliberal thinkers that the problem extended beyond that of economic security. A job also provided dignity and a sense of purpose, and it was in this sense that the goal of maintaining high levels of employment was considered consistent with a liberal agenda (Röpke 1950). For some, like Röpke, this could even include a consideration of the type of jobs that the economy had to offer.

The second problem, that of the 'massification' of society posed a far more serious challenge to the liberals gathered at the Colloque Walter Lippmann (CWL) and later at the Mont Pèlerin Society (MPS). At the CWL Alexander Rüstow pointed out the problem clearly: "it is wholly useless to endlessly extol the economic advantages of a system that one has come to despise, just as it would be ineffective to extol the modern comforts of a city residence to someone who is only willing to accept country living" (Reinhoudt and Audier 2018, 158). The problem of mass society went beyond the economic sphere. If the liberal system could not provide the type of life that individuals aspired to, then it would not be attractive to people. Posed as such it was nearly an insurmountable challenge, after all if individuals did not desire freedom and economic prosperity, then what could liberalism offer? ${ }^{1}$

But for the early neoliberals, most clearly in the work of Rüstow and Wilhelm Röpke, but also in that of Hayek, a different type of analysis was developed. The

\footnotetext{
${ }^{1}$ A question that kept haunting neoliberals, see for example Buchanan (2005).
} 
problem, they argued, was not the wishes of individuals, but rather with the institutional and social context, which had given rise to illiberal demands. The problem, they argued, was not with human nature, but rather with the context of modern society, in which demands for security and equality could come to trump the demand for individual freedom and self-determination. ${ }^{2}$ It was for that reason that many of them felt close to the project of Tocqueville, who had praised the social and institutional context of $19^{\text {th }}$-century America, precisely for the way it had stimulated individualism, and a liberal outlook on life.

Many of such preconditions were no longer present during the interwar period. The nature of work had fundamentally altered, provided people even had a job. Urbanization was giving rise to a completely new way of life. And the definitive rise of the nation-state, anything but a given in $19^{\text {th }}$-century Central Europe, went along with a national democracy, with full suffrage. The new political parties, and unions, mobilized people in increasingly great numbers. But there were also major changes in the intimate private sphere of the family and religion. Various neoliberal thinkers pointed to different subsets of such developments to diagnose their times, but virtually all of them agreed that most of the tendencies of the age had not developed in the direction of a social and cultural context that fostered individualism. Although he represented the most conservative side of the neoliberals these worries are most extensively discussed in the work of Röpke (1948). But they are equally present in the work of Hayek (1948) during this period, for example, in his work on individualism.

The challenge for a new liberal order was thus not merely to ensure economic freedom, but also to provide the preconditions that would lead to the desire for an individualistic social order. Some sought this through decentralization; Swiss federalism, for example, remained an attractive ideal to various neoliberal thinkers. Others sought to depoliticize larger parts of society, not merely to counter an encroaching state from intervening in the economic order, but also to secure space for civil society and the private sphere. And as some recent critics have pointed out the neoliberals also sought to conceptualize the market as an alternative political domain: a sphere where one could express one's preferences and develop independence (Brown 2015; Olsen 2019).

But there was also a deeper tension in early neoliberal thought. Was the market primarily attractive because it was a sphere of discipline? A sphere where individual idiosyncrasies were kept in check by competitive forces, and where exaggerated promises which dominated the political sphere would not be able to survive? Or was it a sphere of liberation, where individuals could express their (minority) preferences, where exit was a much more realistic option than in other domains of social life, and where traditional morality did not hold as strong a grip?

${ }^{2}$ Hayek's later arguments about evolved social(ist) instincts thus represent a similar worry that perhaps individuals do not desire liberalism (Hayek 1988). 


\section{Intermediate Emancipatory Moments?}

The emancipatory agenda, however, never fully developed. It appears that neoliberals had enough trouble agreeing on the economic order, so that the social and cultural agenda faded into the background. Although Burgin (2012) might have overemphasized the importance of Milton Friedman in his history of the MPS, it is hard not to agree with his overall assessment that economic themes came to dominate in the society. The intellectual leaders were increasingly professional economists, at the expense of the broader social scientific and humanities scope that Hayek had originally sought for the society.

What was more, as Melinda Cooper (2017) has recently shown in her critical history of neoliberalism, the movement formed an alliance with neoconservatives in the United States in the 1970s. She might have added that a similar process took place in Germany with the Christian Democrats. This aligned the neoliberals with a conservative social agenda in which traditional family values and structures were favored. Traditional families were entitled to higher benefits or to an increased number of deductions. And welfare programs were directed at family units rather than individuals.

But at least one interesting emancipatory argument came from an unexpected corner. Michel Foucault, who did much to inspire the modern historiographic trend to study neoliberalism and its origins, developed an ambivalence toward the program, or at least so much has been suggested by a growing group of Foucault scholars. They have drawn attention to a number of elements which Foucault found attractive in the work of Gary Becker, who, next to Milton Friedman, was central at the Chicago School.

The first element that intrigued Foucault was the theory of human capital. It might be argued that human capital theory put humans back at the center stage of economic analysis, as opposed to much of $19^{\text {th }}$-century economics which was all about production. Human capital theory, of course, can be interpreted similarly along productivity lines: what level of education among the population is required in order to ensure growth? But it could equally be interpreted differently, as Gary Becker himself stressed, as an argument that education, which we value anyway, has the additional benefit of leading to more economic prosperity. More importantly it would create educational opportunities for disadvantaged groups, or as Becker said about the groups that would benefit from education: “they don't have enough power, and they're neglected in society" (Becker, Ewald, and Harcourt 2011, 19). ${ }^{3}$

However emancipatory for the individual this sounds, Melinda Cooper has correctly demonstrated that modern educational programs do not always manage to empower the disadvantaged individual. If funding of education relies too strongly on

\footnotetext{
${ }^{3}$ It is worth pointing out that a thinker of the left like Jan Tinbergen (1960; 1975) equally viewed human capital theory and education as a prime factor in alleviating inequality.
} 
support systems like the family then individuals from disadvantaged backgrounds are unlikely to have proper access to it.

An interpretation analogous to that of human capital of Becker's theory of discrimination is plausible. Education, which is desirable in the first place, is rewarded in the market. Discrimination, which is undesirable, is punished in the market. Becker's theory is an exploration of the institutional contexts under which discrimination is a costly practice. Although Becker's analysis (1993) was not conclusive it strongly suggested that under most conditions market competition will make discrimination costly, and it is likely to disappear for that reason. As he emphasized, he thought of his own theory as an: "an uplifting point of view, rather than a limiting point of view" (Becker, Ewald, and Harcourt 2011).

But it is unclear whether it was this uplifting message that was most appealing to Foucault. Especially since the other aspect of Becker's thought that intrigued Foucault was his theory of crime and more generally his theory of individuality, which was virtually devoid of anthropological or humanistic underpinnings. Instead, devoid of moral or humanistic concerns, it normalized crime as just another human activity. The resulting neoliberal theory of governmentality of crime was hence, in the work of Becker, not cast in a normative mold, but rather in efficiency terms: How much crime can we afford? It might be odd to believe there are the seeds of an emancipatory idea here, but that is precisely what Foucault believed. And the emancipatory idea he identified in the work of Becker is strongly at odds with that of the early neoliberals.

Röpke, Rüstow, and Hayek sought a return to humanistic or Christian values, but in Becker's work we find no such suggestions. And this is precisely what made it attractive to Foucault, who sought to limit the disciplinary power of the state. Whereas the early neoliberals sought to strengthen old family and religious structures, and overall a bourgeois organization of society, Foucault thought of this as a disciplinary and illiberal program. Precisely the fact that the state would enforce a particular lifestyle, he believed, was one of the great modern dangers. The neutral way of looking at 'crime' present in Becker's work did not condemn criminal behavior, but instead sought to reduce its socially harmful effects. It was neutral cost-benefit analysis, devoid of moralizing (Behrent 2009).

A similar perspective could be applied to education. Although it will certainly hurt some liberal and humanistic sensibilities. Education was not inherently desirable, the question was merely how much education was necessary for a given job. Education, from this perspective is a disciplinary mechanism that a liberal should look at with a healthy dose of suspicion. Is it truly necessary that all individuals spend most of their childhood and even some of their early adulthood in uniform educational institutions (Caplan 2018)? For Foucault after all institutions, such as jails but also traditional schools, were important disciplinary instruments.

And Foucault was onto something. The 1968 movement sought liberation from many of the traditional and hierarchical institutions, which were decried as oppressive. The second feminist wave of the 1970s, and the fight for gay rights in the decades 
since, were attempts to break the disciplinary force of the modern state. In that sense Becker's radical individualism in his A Treatise on the Family (1981) fits right in with the attempts of these groups to emancipate themselves from the oppressive sides of family life. The emergence of subcultures in which drug use or other alternative lifestyles were pursued provided sites of experimentation that could be evaluated on a neutral basis - did they harm others? - rather than evaluated based on normative and aesthetic criteria.

The theme of experimentation, and the market as a site of experimentation is precisely something that becomes more focal around this period (Hayek 1978; Buchanan and Vanberg 1991). And experimentation, as Nozick (1974) so forcefully argued, requires a large degree of self-governance. This theme of self-governance, in which communities and groups are granted the right to govern themselves and to live according to a set of 'local constitutions' combined the federalist ideal of the past which had been largely rooted in regional or religious identities, with the modern ideal of subcultures and niche preferences (and markets). Such perspectives can also be found in the work of Elinor Ostrom (1990) and Vincent Ostrom (1997), who maintain unsurprising popularity with countercultural groups. But its most consistent defense is perhaps provided by Chandran Kukathas in The Liberal Archipelago (2003).

In relation to this shift we should also certainly mention the renewed prominence of the entrepreneur in his radical Schumpeterian guise. It all signaled the fact that change was again evaluated positively by liberals. From within neoliberalism, and in dialogue with its critics, it is thus possible to discern an alternative agenda of emancipation. One that does not seek to restore the bourgeois ideal of the $19^{\text {th }}$ century, but one that is willing to question traditional bourgeois institutions based on how they restrain or enable individual development. An alternative program of what is sometimes called Vitalpolitik in ordoliberal circles.

It is worth pointing out that the seeds for this pluralist emancipation agenda can be found among some of the ordoliberals. The notion of 'disempowerment' in the work of Walter Eucken and Franz Böhm contains some of the seeds of this pluralist emancipation agenda of self-governance (Kolev 2015). Their quest to break corporate power, and concentrated power more generally, fits well with the dispersed nature of power that Foucault analyzed. But they certainly do not yet take the step to also question institutions such as the bourgeois family. It is in part Melinda Cooper's achievement to show that despite all the purported individualism of the neoliberals, they in fact ended up protecting a number of quite traditional social institutions. ${ }^{4}$ In that sense the emancipatory agenda that Foucault discerned, and which Becker explored, is an unfulfilled promise. A program that is not merely politically underdeveloped, but also intellectually incomplete.

\footnotetext{
${ }^{4}$ There is also a Rawlsian way of making this point. What Cooper demonstrates is that neoliberals did not sufficiently strive for neutrality with regard to lifestyles. In fact the state ended up promoting certain ways of living (together) over others.
} 


\section{Toward an Emancipatory Agenda}

It is my strong conviction that one of the core liberal ideas that is still alive today is the desire of people to give shape to their own lives. This desire expresses itself clearly in the digital world which has given rise to more communities than one could have ever imagined. We are also seeing a strong demand coming from these communities to govern themselves, the experimentation with digital currencies is just one sign of it.

If a core ideal of the liberal Enlightenment was the goal of autonomy then this autonomy has perhaps come within closer reach than ever before. It is facilitated precisely by the changes in modern society, and the breaking up of many of the traditional forms of community. $19^{\text {th }}$-century liberals such as John Stuart Mill strongly supported and spoke out in favor of such 'experiments in living.' The neoliberals were not quite so certain, as they sought to solidify the individualism of the bourgeois world mostly through a restoration of that world. What we have witnessed after 1968 is the flourishing of youth culture, counter-culture, and more recently digital culture. They are all modern experiments in living, but neoliberals have often been unsure about whether they should support these experiments. The social movements associated with them have campaigned for more freedom in sexual and aesthetic norms, for new forms of living together (even within the family), and for new forms of self-governance.

Most conservatives and many classical liberals have been ambivalent about these changes in society. Hayek famously proclaimed that he was not a conservative, but at least appearances were against him. The neoliberals of the 1940s sought to retain traditional forms of community, and they were unsure whether there were still any socio-cultural institutions left which fostered individualism. They had trouble accommodating their emancipatory agenda beyond that of the $19^{\text {th }}$ century. It is therefore still an open challenge to develop such an agenda. It is that task which is ahead of us. In doing so we can learn much from the progressive critics of neoliberalism, on which I have drawn here repeatedly.

The labor market has changed considerably since the middle of the $20^{\text {th }}$ century. Where the early neoliberals worried about the large corporation and how it undermined individualism and entrepreneurship, the modern economy is largely based around entrepreneurship, start-ups, and human capital. And even for those who work for larger organizations job choices are not career-long commitments, but stepping stones to other jobs. Boltanski and Chiapello (2005) have, again from a critical standpoint, analyzed how the desire for self-development has been facilitated by modern firms. They have argued that firms have found a response to the critique of 1968 , by providing more freedom and space for creativity in the workplace.

Urban life has given rise to more niche-markets than could be imagined in the age of mass-production of the 1950s. It has opened up the opportunity for voluntary associations and 'clubs' of a completely different kind than those imagined by the early neoliberals. The city as a consequence is more than ever the most popular place 
to live (as reflected in the premium that individuals are willing to pay to live there). The mass market has given way to mass diversification. And young people more than ever desire to live in these cities.

In the media landscape similar developments have taken shape. Where mass media dominated the landscape 70 years ago, the internet and social media have opened up a vast array of new possibilities for communication and interaction. These developments are still taking shape, and new issues about competitiveness of the media landscape are cropping up. But to whichever side one is leaning it appears that neoliberals have much to say about how we can order this market, and how the power to control own's own news and cultural consumption should have empowering effects. If a complaint of mass democracy was that it provided insufficient protection for minorities, then the modern fragmented media landscape should be much lauded.

If neoliberals are interested - as they should be - in developing an emancipatory agenda they should embrace these social, economic, and cultural developments and seek to reconnect them to the values of freedom and autonomy. There are more than enough promising ways in which this can be done. It is not even a mere neoliberal agenda; John Stuart Mill's arguments for freedom of lifestyle are more relevant than ever. At the start of the $21^{\text {st }}$ century society has realized a plethora of different lifestyles and subcultures which are sometimes global, and other times as local as ever.

Neoliberals have much to offer to such groups. They can demonstrate to them the value of self-governance and foster it, but also to stimulate the necessary tolerance between groups. They can critique the modern state where it still tries to impose a certain lifestyle or does not allow particular groups to develop theirs. Where necessary it can help rethink the welfare state so that it does not become a constraining or disciplinary force, by untying welfare arrangements from traditional family patterns or perhaps even from traditional work patterns such as in the proposals for a universal basic income.

This is all the more relevant in an age when the progressives seem to have lost much of the faith in the individual who has to be nudged into the right decisions, and needs to be protected from fake news and the influence of unwanted groups and views. Conservatives, on the other hand, increasingly seek to shelter those within the nation from outside influences, so that the culture and group can be kept pure. In such circumstances it is easy to become fatalist about the future of liberalism. When the world is ruled by authoritarian leaders, and conservatives are increasingly turning away from liberalism (even in its purely economic guise), it is high time to rediscover a constructive program for the future. Precisely as the neoliberals sought to offer, in the words of Henry Simons, a positive program. It is in such circumstances that a positive emancipatory agenda that puts faith in the individual is needed more than ever. In order to do so, the new neoliberals of this generation should develop the courage to embrace the future.

For that the spirit of the neoliberals can still be inspiring. In Popper's words: "If we wish to remain human, then there is only one way, the way into the open society. We 
must go on into the unknown, courageously" (1945a, 177). And Hayek echoes these sentiments, noting: "Man is not and never will be the master of his fate: his very reason always progresses by leading him into the unknown and unforeseen where he learns new things" $(1982,176)$. If we can place faith in that future, we can perhaps also hope that life for individuals will be better there.

\section{References}

Becker, G. S. 1981. A Treatise on the Family. Cambridge: Harvard University Press.

Becker, G. S. 1993. “The Economic Way of Looking at Behavior.” Journal of Political Economy 101 (3): $385-409$.

Becker, G. S., F. Ewald, and B. E. Harcourt. 2011. "Becker on Ewald on Foucault on Becker: American Neoliberalism \& Michel Foucault's 1979 Birth of Biopolitics Lectures.” Carceral Notebooks: Neoliberalism and Risk 7: 1-35.

Behrent, M. C. 2009. "Liberalism Without Humanism: Michel Foucault and the Free-Market Creed, 1976-1979.” Modern Intellectual History 6 (3): 539-68.

Böhm, F., W. Eucken, and H. Großmann-Doerth. 1989. "The Ordo Manifesto of 1936." In Germany's Social Market Economy: Origins and Evolution, edited by A. Peacock and H. Willgerodt, 15-26. New York: St. Martin's Press.

Boltanski, L. and E. Chiapello. 2005. The New Spirit of Capitalism. London: Verso.

Brown, W. 2015. Undoing the Demos: Neoliberalism's Stealth Revolution. New York: Zone Books.

Buchanan, J. M. 2005. “Afraid to Be Free.” Public Choice 124: 19-31.

Buchanan, J. M., and V. J. Vanberg. 1991. "The Market as a Creative Process.” Economics and Philosophy 7 (2): 167-86.

Burgin, A. 2012. The Great Persuasion: Reinventing Free Markets since the Depression. Cambridge: Harvard University Press.

Caplan, B. 2018. The Case Against Education: Why the Education System Is a Waste of Time and Money. Princeton: Princeton University Press.

Cooper, M. 2017. Family Values: Between Neoliberalism and the New Social Conservatism. Cambridge: MIT Press.

Dekker, E. 2016. The Viennese Students of Civilization: The Meaning and Context of Austrian Economics Reconsidered. New York: Cambridge University Press.

Dekker, E. 2019. “On Emancipators, Engineers, and Students: The Appropriate Attitude of the Economist." Review of Austrian Economics 33 (1/2): 55-68.

Grudev, L. 2018. "The Secondary Depression: An Integral Part of Wilhelm Röpke's Business Cycle Theory." In Wilhelm Röpke (1899-1966): A Liberal Political Economist and Conservative Social Philosopher, edited by P. Commun and S. Kolev, 133-54. Cham: Springer.

Hayek, F. A. 1944. The Road to Serfdom. Chicago: University of Chicago Press. 
Hayek, F. A. 1948. Individualism and Economic Order. Chicago: University of Chicago Press.

Hayek, F. A. 1978. "Competition as a Discovery Procedure." In New Studies in Philosophy, Politics, Economics and the History of Ideas, 179-90. Chicago: University of Chicago Press.

Hayek, F. A. 1982. “The Three Sources of Human Values.” In Law, Legislation and Liberty: The Political Order of a Free People, Vol. 3, 153-76. London: Routledge.

Hayek, F. A. 1988. The Fatal Conceit: The Errors of Socialism. The Collected Works of F. A. Hayek, Vol. 1, edited by W. W. Bartley III. London: Routledge.

Kolev, S. 2015. "Ordoliberalism and the Austrian School." In The Oxford Handbook of Austrian Economics, edited by P. J. Boettke and C. J. Coyne, 419-44. New York: Oxford University Press.

Kukathas, C. 2003. The Liberal Archipelago: A Theory of Diversity and Freedom. Oxford: Oxford University Press.

Mises, L. v. 1978. Notes and Recollections. South Holland: Libertarian Press.

Nozick, R. 1974. Anarchy, State \& Utopia. New York: Basic Books.

Olsen, N. 2019. The Sovereign Consumer: A New Intellectual History of Neoliberalism. London: Palgrave Macmillan.

Ostrom, E. 1990. Governing the Commons: The Evolution of Institutions for Collective Action. Cambridge: Cambridge University Press.

Ostrom, V. 1997. The Meaning of Democracy and the Vulnerability of Democracies: A Response to Tocqueville's Challenge. Ann Arbor: University of Michigan Press.

Popper, K. R. 1945a. The Open Society and Its Enemies: The Spell of Plato, Vol. 1. London: Routledge.

Popper, K. R. 1945b. The Open Society and Its Enemies: The High Tide of Prophecy, Hegel, Marx and the Aftermath, Vol. 2. London: Routledge.

Reinhoudt, J. and S. Audier. 2018. The Walter Lippmann Colloquium: The Birth of Neo-Liberalism. London: Palgrave Macmillan.

Röpke, W. 1948. Civitas Humana. London: William Hodge.

Röpke, W. 1950. The Social Crisis of Our Time. Chicago: University of Chicago Press.

Rüstow, A. 1945. Das Versagen des Wirtschaftsliberalismus als religionsgeschichtliches Problem. Zurich: Europa Verlag.

Tinbergen, J. 1960. "The Place of Education in the Economy." Giornale degli Economisti e Annali di Economia 19 (1/2): 3-12.

Tinbergen, J. 1975. Income Distribution: Analysis and Policies. New York: North Holland. Wieser, F. v. 1910. Recht und Macht: Sechs Vorträge. Leipzig: Duncker \& Humblot. 